\title{
TITRIMETRIC ASSAY OF LISINOPRIL IN AQUEOUS AND NON-AQUEOUS MEDIA
}

\author{
K.Basavaiah ${ }^{1 *}$, K. Tharpa ${ }^{1}$, K.B. Vinay ${ }^{2}$ \\ ${ }^{1}$ Department of chemistry, University of Mysore, Manasagangotri, Mysore-57006, India \\ ${ }^{2}$ Advinus Therapeutics Pvt. Ltd., Peenya II Phase, Bangalore-560058, India. \\ "Corresponding Author E-mail: basavaiahk@yahoo.co.in
}

\begin{abstract}
Four simple titrimetric procedures are described for the determination of lisinopril (LNP) in bulk and in pharmaceuticals based on the neutralization of basic-amino and acidic carboxylic acid groups present in LNP. Method A is based on the neutralization of basic amino groups using perchloric acid as titrant in anhydrous acetic acid medium. Method B, method C and method $\mathrm{D}$ are based on neutralization of carboxylic acid group using $\mathrm{NaOH}$, sodium methoxide and methanolic $\mathrm{KOH}$, as titrants, respectively. Method A is applicable over 2.0-20.0 mg range and the calculations are based in the molar ratio of 1:2 ( $\left.\mathrm{LNP}: \mathrm{HClO}_{4}\right)$. Method $\mathrm{B}$, method $\mathrm{C}$ and method D are applicable over $2.0-20.0 \mathrm{mg}, 1.0-10.0 \mathrm{mg}$ and $5.0-15.0 \mathrm{mg}$ range, respectively, and their respective molar ratios are 1:1 (LNP:NaOH), 1:2 (LNP: $\left.\mathrm{CH}_{3} \mathrm{ONa}\right)$ and $1: 1$ (LNP:KOH). Intraday and inter day accuracy and precision of the methods were evaluated and the results showed intra- and inter-day precision less than $2.7 \%$ (RSD), and accuracy of $<2.5$ $\%$ (RE). The developed methods were applied to determine LNP in tablets and the results were validated statistically by comparing the results with those of the reference method by applying the Student's t-test and F-test. The accuracy was further ascertained by recovery studies via standard addition technique. No interferences from common tablet exipients was observed.
\end{abstract}

Key words: Lisinopril, titrimetry, potentiometry, pharmaceuticals

\section{Introduction}

Lisinopril, 1-[6-Amino-2-(1-carboxy-3phenyl-propylamino)-hexanoyl]-pyrrolidine-2carboxylic acid, is a lysine derivative of enalaprilat, the active metabolit of enalapril. It is an angiotensin converting enzyme (ACE) inhibitor used in the treatment of hypertension, heart failure, acute myocardial infarction and preventing renal and retinal complications of diabetics [1] and was introduced into therapy in 1990s [2]. The official methods for the determination of LNP are potentiometric acid-base titration [2] and HPLC [3] using actylsilane column at $50{ }^{\circ} \mathrm{C}$ and phos- phate solution-acetronitrile $(96: 4 \mathrm{v} / \mathrm{v})$ as mobile phase.

Certain successful attempts have been made for the determination of LNP in pharmaceuticals using different analytical techniques. Determination of LNP in dosage forms using visible spectrophotometry [4-12] requires either pre derivatisation, heating step or use of organic solvents as reaction medium. Use of spectrofluorimetry technique $[6,7,13,14]$ are also based on the derivatisation of the drug prior to measurement, and involve heating step and longer contact times. UV-derivative spectrophotometry has been utilized for LNP determination either alone [15-21] or in binary mixture with amlodipine [22] or hydro- 
chlorothiazide [23]. These methods are mostly applicable in relatively high concentrations. Polarographic $[12,24,25]$ determination of LNP are rather complicated and they are not so sensitive. Other techniques include- gas chromatography [26], HPTLC-densitometry [16], capillary electrophoresis [27] and HPLC [28-31]. Though the existing methods are sensitive yet they are expensive. Cost effective analytical technique such as titrimetry is still needed in various quality control laboratories in the developing countries.

There is only one report, an official method [2], on the use of titrimetry method for the determination of LNP. The method consisted of the titration of the aqueous solution of the tablet containing LNP with $0.1 \mathrm{M} \mathrm{NaOH}$ potentiometrically and requires fairly large quauntities of LNP for each titration. The present manuscript describes four sensitive titrimetric methods for the determination of LNP in both pure form and in tablet form. The methods make use of the two amino groups and one carboxylic acid functional groups present in the molecule. The developed methods are more simple than many existing methods besides being applicable to smaller amounts compared to the lone titrimetric method available [2].

\section{Experimental}

\section{Apparatus}

Potentiometric titration was performed with an Elico 120 digital $\mathrm{pH}$ meter provided with a combined glass-SCE electrode system. The $\mathrm{KCl}$ of the salt bridge was replaced with saturated solution of $\mathrm{KCl}$ in methanol.

\section{Materials and reagents}

LNP was kindly provided by Cipla Ltd., India, and was used as received. Pharmaceutical preparations of LNP, such as Hipril (Micro Carsyon Ltd.), Lipril (Lupin laboratories Ltd.), and Listril (Torrent Pharmaceutical Ltd.) were purchased from the local market. All other reagents and solvent used were of analytical grade and they were purchased from either Merck, Loba Chemie and S.d. Fine Chem of Mumbai, India.

A $0.01 \mathrm{M}$ perchloric acid (standardized against $0.01 \mathrm{M}$ potassium dihydrogen phthalate) and $0.5 \%$ crystal violet indicator was prepared in glacial acetic acid for method A. A $0.01 \mathrm{M} \mathrm{NaOH}$ (standardized against $0.01 \mathrm{M}$ potassium hydrogen phthalate) and $0.2 \%(\mathrm{w} / \mathrm{v})$ phenolphthalein indicator were prepared in ethanol for method B. A $0.005 \mathrm{M}$ sodium methoxide (standardized against benzoic acid) was prepared in 3:1 benzene: methanol and $0.2 \%(\mathrm{w} / \mathrm{v})$ phenolphthalein in same solvent for method C. A $0.005 \mathrm{M} \mathrm{KOH}$ (standardized against benzoic acid) was prepared in methanol for method D.

A stock standard solution of LNP containing $2 \mathrm{mg} / \mathrm{ml}$ was prepared in glacial acetic acid $(\operatorname{method} \mathrm{A}), 2 \mathrm{mg} / \mathrm{ml}$ in water $(\operatorname{method} \mathrm{B}), 1 \mathrm{mg} /$ $\mathrm{ml}$ in 3:1 benzene:methanol (method $\mathrm{C})$ and $1 \mathrm{mg} /$ $\mathrm{ml}$ in methanol (method D).

\section{Procedures}

\section{Method A}

Different volumes (1-10 ml) of standard solution containing $2 \mathrm{mg} / \mathrm{ml}$ LNP were taken in a $100 \mathrm{ml}$ titration flask and the volume was madeup to $10 \mathrm{ml}$ with glacial acetic acid. Two drops of crystal violet indicator were added and the solution titrated against standardized solution of $0.01 \mathrm{M}$ perchloric acid to a blue end point.

\section{Method B}

$10.0 \mathrm{ml}$ aliquot of standard solution containing 2.0-20.0 mg of LNP was measured accurately and transferred into a $100 \mathrm{~mL}$ titration flask. Two drops of $0.2 \%$ phenolphthalein were added and titrated against standardized solution of 0.005 $\mathrm{N}$ sodium hydroxide to a first appearance of pink color end point. 


\section{Method C}

Varying aliquots (1-10 $\mathrm{ml})$ of $1 \mathrm{mg} / \mathrm{ml} \mathrm{stan}$ dard LNP solution were accurately measured into a titration flask and volume adjusted to $10 \mathrm{ml}$ with 3:1 benzene: methanol. Two drops of $0.2 \%$ phenolphthalein were added and titrated against standardized solution of $0.005 \mathrm{M}$ sodium methoxide to a first appearance of pink color end point.

\section{Method D}

Different volumes $(1-10 \mathrm{ml})$ of standard solution containing $1 \mathrm{mg} / \mathrm{ml} \mathrm{LNP}$ were taken in a $50 \mathrm{ml}$ beaker and volume madeup to $20 \mathrm{ml}$ with methanol. The titration was carried potentiometrically against standardized solution of $0.005 \mathrm{M}$ $\mathrm{KOH}$.

All titrations were carried in a well closed container in order to avoid atmospheric carbon dioxide from dissolving into the solutions.

The amount of LNP in the aliquot was computed from the following formula:

$$
\text { Amount }(\mathrm{mg})=\frac{\mathrm{V} \times \mathrm{Mw} \times \mathrm{S}}{\mathrm{n}}
$$

where $\mathrm{V}=\mathrm{ml}$ of titrant reacted

$\mathrm{M}_{\mathrm{w}}=$ relative molecular mass of drug

$\mathrm{S}=$ strength of titrant, moles/L

$\mathrm{n}=$ number of moles of titrant reacting with per mole of LNP.

\section{Procedure for the determination of lisinipril in tablets}

Twenty tablets were weighed accurately and ground into a fine powder. Four portions of the powder equivalent to $200 \mathrm{mg}$ or $100 \mathrm{mg}$ of LNP was accurately weighed into a $100 \mathrm{~mL}$ volumetric flask and extraction was done by shaking for half an hour with $40 \mathrm{ml}$ of solvent specified under each methods; then, the volume was diluted to the mark with the respective solvents, mixed well and filtered using a Whatman No. 42 filter paper. First $10 \mathrm{~mL}$ portion was discarded and subsequent amount of the tablet extract was subjected to titration by following the procedures mention under each methods.

\section{Results and Discussion}

Due to non-leveling properties of organic solvents, many weak organic acids and bases are quantitatively titrated based on the neutralization due to the formation of a coordinate bond between an acid and a base. Basisity of two amino groups (a primary and a secondary) present in LNP was enhanced in glacial acetic acid which acts as a protogenic solvent and titrated as amine acetates with perchloric acid. The end point was detected by change of protolytic equilibrium of the crystal violet indicator. The reaction stiochiometry found to be 1:2 ( $\left.\mathrm{LNP}: \mathrm{HClO}_{4}\right)$, inferring both the amines are involved in the titration. Method B involved neutralization of carboxylic acid group present in LNP in aqueous medium by $\mathrm{NaOH}$ using phenolphthalein as indicator. One of the carboxylic acid groups at the $\alpha$-amino position is too weak to titrate in aqueous medium and hence the molar ratio found to be 1:1 (LNP: $\mathrm{NaOH})$; where as in method $\mathrm{C}$, both the carboxylic acid groups show enhanced acidic property in 3:1 benzene-methanol solvent medium when titrated against sodium methoxide using phenolphthalein as indicator as inferred by the reaction stiochiometry of 1:2 (LNP:MeONa). Benzene-methanol (3:1) solvent has been successfully used [32-35] in titrating many weak organic acids since the entire titration curves lies within the potential range of the solvent. Generally, benzene being a relatively neutral solvent of low dielectric constant is used in conjuction with any acidic or basic solvent in order to increase the sensitivity of the titration end-points and for differential titrations. In potentiometric titration (method D), LNP in methanol was titrated against methanolic $\mathrm{KOH}$ and it shows one of the carboxylic group is too weak to titrate quantitatively and at the same time corresponding peak was insignificantly small. 


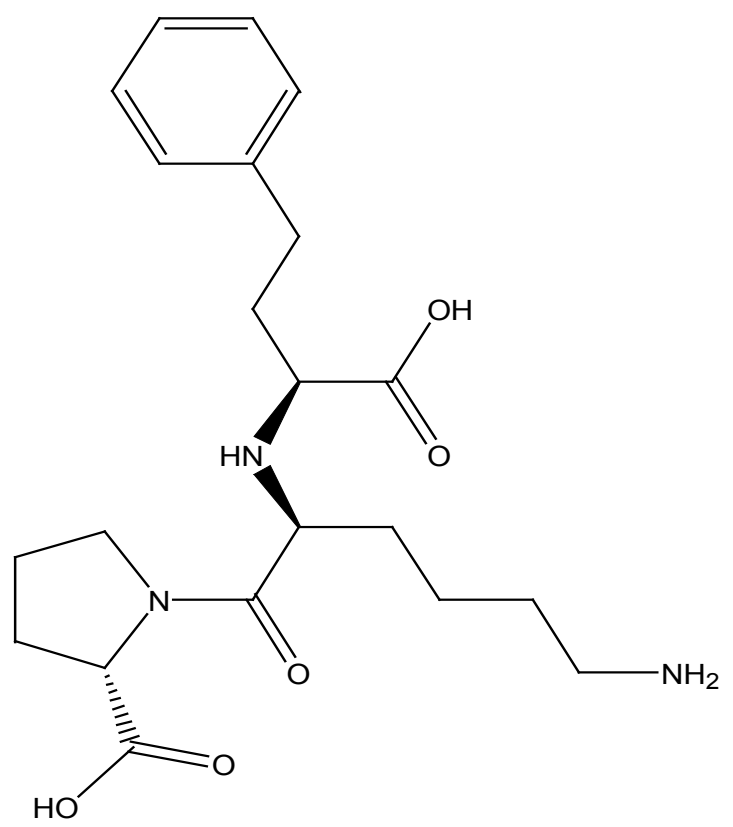

Fig. 1. Structure of lisinopril

Therefore, the reaction stiochiometry of 1:1 was used for the calculation purpose. Further, a potentiometric titrations was performed by varying the ratios of benzene-methanol as solvent and sodium methoxide as titrant and found that the peaks are rather broad and distorted. Similarly, $5: 1$ benzene-methanol shows lot of fluctuations in the potential reading.

\section{Method validation}

Method validations are done according to the present ICH guidelines [36].

\section{Selectivity}

The proposed methods were tested for selectivity by placebo blank and synthetic mixture analyses. A placebo blank containing talc $(20 \mathrm{mg})$, starch (15 mg), lactose (5 mg), calcium carbonate $(10 \mathrm{mg})$, calcium dihydrogenorthophosphate (10 $\mathrm{mg})$, methyl cellulose (5 mg), sodium alginate (15 $\mathrm{mg})$ and magnesium stearate $(10 \mathrm{mg})$ was prepared, extracted with respective solvents mentioned under four different methods and solution made as described under "procedure for tablets". A convenient aliquot of solution was subjected to analysis by titrimetry according to the recommended procedures. In all the cases, there was no measurable consumption of titrant suggesting the non-interference by the inactive ingredients.

A separate experiment was performed with synthetic mixture. To the placebo blank of similar composition, 100 or $200 \mathrm{mg}$ of LNP was added, homogenized and the solution of the synthetic mixture was prepared as done under "procedure for tablets". Ten $\mathrm{ml}$ of the resulting solution was assayed $(n=5)$ which yielded a \% recovery of $101.3 \pm 0.62-104 \pm 0.23$. These results complement the findings of the placebo blank analysis with respect to selectivity.

\section{Accuracy}

The accuracy of the proposed methods was determined by performing replicate determinations. The intra-day and inter-day variation in the analysis of LNP was measured at three different levels. The accuracy of an analytical method expresses the closeness between the reference value and the found value. Accuracy was evaluated as percentage relative error between the measured and taken amounts/concentrations. The results of this study are compiled in Table 1 and speak of the excellent accuracy of the results.

\section{Precision}

The precision of the methods was evaluated in terms of intermediate precision (intra-day and inter-day). Three different concentrations of LNP within the range in each method were analysed in seven replicates during the same day (intra-day precision) and five consecutive days (inter-day precision). The RSD values of intra-day and interday studies for LNP showed that the precision of the methods was good. 
Table 1. Evaluation of intra-day and inter-day accuracy and precision

\begin{tabular}{|c|c|c|c|c|c|c|c|}
\hline \multirow{2}{*}{ Methods } & \multirow{2}{*}{$\begin{array}{l}\text { LNP taken, } \\
\text { mg }\end{array}$} & \multicolumn{3}{|c|}{ Intra-day accuracy and precision } & \multicolumn{3}{|c|}{ Inter-day accuracy and precision } \\
\hline & & $\begin{array}{l}\text { LNP found, } \\
\text { mg }\end{array}$ & $\begin{array}{c}\mathrm{RE} \\
\%\end{array}$ & $\begin{array}{c}\mathrm{RSD} \\
\%\end{array}$ & $\begin{array}{l}\text { LNP found, } \\
\text { mg }\end{array}$ & $\begin{array}{c}\mathrm{RE} \\
\%\end{array}$ & $\begin{array}{c}\text { RSD } \\
\%\end{array}$ \\
\hline \multirow{3}{*}{ Method A } & 2.0 & 2.04 & 2.0 & 0.50 & 2.05 & 2.5 & 1.90 \\
\hline & 10.0 & 10.16 & 1.6 & 0.12 & 10.18 & 1.8 & 2.10 \\
\hline & 20.0 & 20.21 & 1.0 & 1.0 & 20.30 & 1.5 & 2.00 \\
\hline \multirow{3}{*}{ Method B } & 5.0 & 5.06 & 1.2 & 2.1 & 5.10 & 2.0 & 2.58 \\
\hline & 10.0 & 10.22 & 2.2 & 1.7 & 10.22 & 2.2 & 1.63 \\
\hline & 15.0 & 15.30 & 2.0 & 2.0 & 15.3 & 2.0 & 2.40 \\
\hline \multirow{3}{*}{ Method C } & 3.0 & 3.01 & 0.3 & 0.3 & 3.07 & 2.3 & 1.56 \\
\hline & 6.0 & 6.10 & 1.7 & 0.12 & 6.06 & 1.0 & 2.00 \\
\hline & 9.0 & 9.05 & 0.6 & 0.2 & 9.20 & 2.2 & 2.10 \\
\hline \multirow{3}{*}{ Method D } & 4.0 & 4.02 & 0.5 & 2.0 & 4.06 & 1.5 & 2.70 \\
\hline & 6.0 & 6.10 & 1.7 & 0.3 & 6.14 & 2.3 & 1.56 \\
\hline & 8.0 & 8.10 & 1.3 & 1.8 & 8.20 & 2.5 & 2.11 \\
\hline
\end{tabular}

\section{Ruggedness}

Method ruggedness was expressed as the RSD of the same procedure applied by four different analysts as well as using three different burettes. The inter-analyst RSD were within $1.1 \%$ whereas the inter-burettes RSD for the same LNP concentrations ranged from $2.54-3.14 \%$ suggesting that the developed method was rugged.

\section{Application to tablet analysis}

Commercial LNP tablets were analysed using the developed methods and also a literature method (8) (reference method). The method consisted of the measurement of the aborbance of the charge transfer complex formed between LNP and para-chloranilic acid in methanol medium at 525 $\mathrm{nm}$. The results obtained were compared statistically by the Student's t-test and the variance-ratio F-test. The calculated t- and F- values did not exceed the tabulated values at the $95 \%$ confidence level and for four degrees of freedom, indicating close similarity between the proposed methods and the reference method with respect accuracy and precision. These results are summarized in Table. 2. 
Table. 2. Results of analysis of tablets by the proposed methods.

\begin{tabular}{|c|c|c|c|c|c|c|}
\hline \multirow{2}{*}{$\begin{array}{c}\text { Tablets } \\
\text { analysed } * *\end{array}$} & \multirow{2}{*}{$\begin{array}{c}\text { Label } \\
\text { claim, } \\
\text { mg/tablet }\end{array}$} & \multicolumn{5}{|c|}{ Found* (Percent label claim \pm SD) } \\
\hline & & $\begin{array}{c}\text { Reference } \\
\text { method }\end{array}$ & Method A & Method B & Method C & Method D \\
\hline \multirow{3}{*}{ Normoprila } & \multirow{3}{*}{2.5} & \multirow{3}{*}{$98.64 \pm 1.58$} & $99.12 \pm 1.22$ & $98.44 \pm 1.22$ & $97.72 \pm 1.92$ & $99.06 \pm 2.14$ \\
\hline & & & $t=0.59$ & $\mathrm{t}=0.23$ & $\mathrm{t}=0.83$ & $t=0.36$ \\
\hline & & & $\mathrm{F}=2.77$ & $\mathrm{~F}=1.68$ & $\mathrm{~F}=1.48$ & $\mathrm{~F}=1.83$ \\
\hline \multirow{3}{*}{ Liprilb } & \multirow{3}{*}{5.0} & \multirow{3}{*}{$100.5 \pm 9.26$} & $101.2 \pm 1.74$ & $100.1 \pm 0.85$ & $100.8 \pm 0.64$ & $99.42 \pm 1.56$ \\
\hline & & & $\mathrm{t}=0.74$ & $\mathrm{t}=0.59$ & $\mathrm{t}=0.49$ & $\mathrm{t}=1.21$ \\
\hline & & & $\mathrm{F}=1.91$ & $\mathrm{~F}=2.19$ & $\mathrm{~F}=3.88$ & $\mathrm{~F}=1.53$ \\
\hline \multirow{3}{*}{ Hiprilc } & \multirow{3}{*}{10.0} & \multirow{3}{*}{$97.46 \pm 1.76$} & $98.58 \pm 1.14$ & $96.72 \pm 1.36$ & $97.72 \pm 1.04$ & $98.72 \pm 1.42$ \\
\hline & & & $\mathrm{t}=1.22$ & $t=0.75$ & $\mathrm{t}=0.52$ & $\mathrm{t}=1.25$ \\
\hline & & & $\mathrm{F}=2.72$ & $\mathrm{~F}=1.67$ & $\mathrm{~F}=2.86$ & $\mathrm{~F}=1.54$ \\
\hline
\end{tabular}

${ }^{*}$ Mean value of five determinations.

** Marketed by: a. Micro Carsyon, Bangalore (India) b. Torrent pharmaceuticals Ltd. Nalagarh (India) c. Aristo Pharmceuticals Ltd. Mumbai (India)

Tabulated t-value at $95 \%$ confidence level for four degree of freedom is 2.77 .

Tabulated F-value at 95\% confidence level for four degree of freedom is 6.39 .

\section{Recovery study}

To further ascertain the accuracy and reliability of the methods, recovery experiments were performed via standard-addition procedure. Pre-analysed tablet powder was spiked with pure LNP at three different levels and the total was found by the proposed methods. Each determination was repeated three times. The percent recovery of pure LNP added was within the permissible limits indicating the absence of inactive ingredients in the assay.

Table. 3. Accuracy assessment by recovery experiments.

\begin{tabular}{|c|c|c|c|c|c|c|c|c|c|}
\hline \multirow[b]{2}{*}{$\begin{array}{l}\text { Tablets } \\
\text { studied }\end{array}$} & \multicolumn{5}{|c|}{ Method A } & \multicolumn{4}{|c|}{ Method B } \\
\hline & $\begin{array}{l}\text { LNP in } \\
\text { tablet, } \\
\mathrm{mg}\end{array}$ & $\begin{array}{l}\text { LNP in } \\
\text { tablet, } \\
\text { mg* }\end{array}$ & $\begin{array}{l}\text { Pure LNP } \\
\text { added, } \\
\text { mg }\end{array}$ & $\begin{array}{l}\text { Total found, } \\
\mathrm{mg}\end{array}$ & $\begin{array}{l}\text { Pure LNP } \\
\text { recovered*, } \\
\text { Percent } \pm \text { SD }\end{array}$ & $\begin{array}{l}\text { LNP in } \\
\text { tablet, } \\
\mathrm{mg}\end{array}$ & $\begin{array}{l}\text { Pure LNP } \\
\text { added, } \\
\text { mg }\end{array}$ & $\begin{array}{l}\text { Total found, } \\
\mathrm{mg}\end{array}$ & $\begin{array}{l}\text { Pure LNP } \\
\text { recovered*, } \\
\text { Percent } \pm \text { SD }\end{array}$ \\
\hline \multirow{3}{*}{ Lipril } & \multirow{3}{*}{5.0} & 5.06 & 2.5 & 7.59 & $101.2 \pm 1.64$ & 5.01 & 2.5 & 7.55 & $101.6 \pm 0.62$ \\
\hline & & 5.06 & 5.0 & 10.09 & $100.6 \pm 1.20$ & 5.01 & 5.0 & 10.00 & $99.8 \pm 1.06$ \\
\hline & & 5.06 & 10.0 & 15.02 & $99.6 \pm 1.56$ & 5.01 & 10.0 & 15.04 & $100.3 \pm 1.12$ \\
\hline \multirow{3}{*}{ Hipril } & \multirow{3}{*}{10.0} & 4.93 & 2.5 & 7.39 & $98.4 \pm 1.76$ & 4.84 & 2.5 & 7.27 & $97.2 \pm 1.16$ \\
\hline & & 4.93 & 5.0 & 9.92 & $99.8 \pm 0.95$ & 4.84 & 5.0 & 9.77 & $98.6 \pm 1.05$ \\
\hline & & 4.93 & 10.0 & 15.06 & $101.3 \pm 1.26$ & 4.84 & 10.0 & 14.37 & $95.3 \pm 0.86$ \\
\hline
\end{tabular}




\begin{tabular}{|c|c|c|c|c|c|c|c|c|}
\hline \multirow[b]{2}{*}{$\begin{array}{l}\text { Tablets } \\
\text { studied }\end{array}$} & \multicolumn{4}{|c|}{ Method C } & \multicolumn{4}{|c|}{ Method D } \\
\hline & $\begin{array}{l}\text { LNP in tablet, } \\
\mathrm{mg}\end{array}$ & $\begin{array}{l}\text { Pure LNP } \\
\text { added, } \\
\text { mg }\end{array}$ & $\begin{array}{l}\text { Total found, } \\
\text { mg }\end{array}$ & $\begin{array}{l}\text { Pure LNP } \\
\text { recovered*, } \\
\text { Percent } \pm \text { SD }\end{array}$ & $\begin{array}{l}\text { LNP in tablet, } \\
\mathrm{mg}\end{array}$ & $\begin{array}{l}\text { Pure LNP } \\
\text { added, } \\
\text { mg }\end{array}$ & $\begin{array}{l}\text { Total found, } \\
\mathrm{mg}\end{array}$ & $\begin{array}{l}\text { Pure LNP } \\
\text { recovered*, } \\
\text { Percent } \pm \text { SD }\end{array}$ \\
\hline \multirow{3}{*}{ Lipril } & 4.00 & 2.0 & 6.03 & $101.5 \pm 0.97$ & 4.97 & 2.50 & 7.55 & $103.2 \pm 1.75$ \\
\hline & 4.00 & 4.0 & 8.14 & $103.5 \pm 1.26$ & 4.97 & 5.0 & 10.0 & $100.6 \pm 1.26$ \\
\hline & 4.00 & 6.0 & 10.13 & $102.2 \pm 0.85$ & 4.97 & 10.0 & 15.1 & $101.3 \pm 1.6$ \\
\hline \multirow{3}{*}{ Hipril } & 3.92 & 2.0 & 5.84 & $96.0 \pm 1.24$ & 4.94 & 2.50 & 7.35 & $96.4 \pm 0.96$ \\
\hline & 3.92 & 4.0 & 7.85 & $98.3 \pm 1.52$ & 4.94 & 5.0 & 9.80 & $97.2 \pm 1.18$ \\
\hline & 3.92 & 6.0 & 9.78 & $97.2 \pm 1.36$ & 4.94 & 10.0 & 14.89 & $99.5 \pm 1.46$ \\
\hline
\end{tabular}

${ }^{*}$ Mean value of three determinations

\section{Conclusion}

The proposed methods are selective as the drug contains amino and carboxylic acid groups, which preferentially get neutralized by acid and alkali, respectively. All the methods show no interference from the common excipients and additives. The statistical parameters and the recovery data reveal good accuracy and precision of the proposed methods. Therefore, it is concluded that the proposed methods are simple and selective for the determination of LNP in pure form and commercial dosage forms. Hence, the present approach encourages their successful use in routine analysis of the drug in quality control laboratories.

\section{Acknowledgement}

The Authors are grateful to Cipla India Ltd, Mumbia, India, for providing the pure sample of lisinopril as gift. One of the authors (KT) thanks the authorities of the University of Mysore, Mysore, for permission and facilities. Kalsang Tharpa also gratefully acknowledges the financial help from the Department of Education, Central Tibetan Administration of His Holiness, The Dalai Lama.

\section{References}

[1] Parfitt, K. “The Complete Drug Reference". (1999) 32 nd ed. 898. The Pharamaceutical Press, Martindalle, MA.
[2] The British Pharmacopoeia, Her Majesty's Stationary Office, London, (1998) pp. 799.

[3] The US Pharmacopoeia, 24 $4^{\text {th }}$ revision, Asian Edition, United States Pharmacopoeial Convention, INC, Twinbrook Parkway, Rockville, MD, (2000), pp. 979 and pp. 2149.

[4] G. Parashevas, J. Atta-Politou, M. Koupparis, J. Pharm. Biomed. Anal 8 (2002) 865.

[5] A. Rajasekaran, S. Udayavani, J Indian Chem Soc., 78 (2001) 485.

[6] F.A El-Yazbi, H.H. Abdine, R.A. Shaalan, J. Pharm. Biomed. Anal, 19 (1999) 819.

[7] A. El-Gindy, A. Ashour, L. Abdel-Fattah, M.M. Shabana, J. Pharm. Biomed. Anal 25 (2001) 923.

[8] N. Rahman, N. Anwar, M. Kashif, Farmaco 60 (2005) 605.

[9] R. Asad, M.A. Tariq, U.R. Atta, J. Chin. Chem. Soc 52 (2005) 1055.

[10] R. Nafisur, S. Manisha, H. Md. Nasrul, J. Braz. Chem. Soc 16 (2005) 1001.

[11] N. Rahman, M.R. Siddiqui, S.N.H. Azmi, Chem. Anal. (Warsaw) 52 (2007) 465.

[12] O. Abdel Razak, S.F. Belal, M.M. Bedair, N.S. Barakat, R.S. Haggag, J. Pharm. Biomed. Anal 31 (2003) 701-711.

[13] S.A. Esra, E. Lale, S. Olcay, II Farmaco 58 (2003)165.

[14] C. Zacharis, P. Tzanavaras, , D. Themelis, , G. Theodoridis, , A. Economou, P. Rigas, Anal. Bioanal. Chem 379 (2004) 759.

[15] O. Durisehvar, S. Hulya, J. Pharm. Biomed. Anal. 21(1999) 691.

[16] A. El-Gindy, A. Ashour, L. Abdel-Fattah, M.M. Shabana, J. Pharm. Biomed. Anal 25 (2001) 923.

[17] S. Beata, Acta. Pol. Pharm 61 (2005) 327.

[18] D. Bonazzi, R. Gotti, V. Andrisano, V. Cavrini, J. Pharm. Biomed. Anal 16 (1997) 431.

[19] C.V.N. Prasad, R.N. Saha, P. Parimoo, Pharm. Pharmacol. Commun 5 (1999) 383.

[20] D. Ozer, H. Senel, J. Pharm. Biomed. Anal 21 (1999) 691.

[21] R.C. Mashru, P.P. Parikh, East. Pharm 43 (2000)111.

[22] H.K. Jain, R.K. Agrawal, Indian Drugs 37 (2000) 196. 
[23] N. Erk, Spectrosc-Lett., 31 (1998) 633.

[24] N. El-Enany, F. Belal, S. Al-Ghannam, Mikrochim. Acta 141 (2003) 55.

[25] A. Rajasekaran, S. Murugesan, Asian J. Chem 13 (2001) 1245.

[26] A.B. Avadhanulu, A.R.R. Pantulu, Indian Drugs 30 (1993) 646.

[27] S. Hillaert, K. De Grauwe, and B.W. Van den, J. Chromatogr. A 924 (2001) 439.

[28] D. Ivanoic, M. Medenica, B. Jancic, N. Knezevic, Acta Chromatogr 18 (2007) 143.

[29] E.R.K. Nevin, K. Murat, Ana. Lett 32 (1999) 1131.

[30] R.T. Sane, G.R. Valiyare, U.M. Deshmukh, S.R. Singh, R. Sodhi, Indian Drugs 29 (1992) 558.

[31] A.B. Christopher, S. Jessica, Z. Zack, A.R. Robert, J. Pharm. Biomed. Anal 37 (2004) 559.

[32] S.S.M. Hassan, M.B. Elsayes, Mikrochimica Acta (1973) 801-807.

[33] J.S. Fritz and R.T. Keen, Anal. Chem 25 (1953)179-181. [34] J.S. Firtz and N.M. Lisicki, Anal. Chem 23 (1951) 589.

[35] J. Firtz. Anal. Chem 24 (1952) 306.

[36] International Conference on Hormonisation of Technical Requirements for Registration of Pharmaceuticals for Human Use, ICH Harmonised Tripartite Guideline, Validation of Analytical Procedures: Text and Methodology Q2(R 1), Complementary Guideline on Methodology dated 06 November 1996, incorporated in November 2005, London. 